To Maega | Jurnal Pengabdian Masyarakat

Februari, Vol.5, No.1, hal, 142-149

$\operatorname{ISSN}(P): 2622-6332 ; \operatorname{ISSN}(E): 2622-6340$

http://www.ojs.unanda.ac.id/index.php/tomaega

\title{
Pelatihan Inovasi Produk serta Strategi Pemasaran pada UMKM Bubuk Jahe di Masa Pandemi Covid 19
}

\author{
Muhammad Saputra ${ }^{1 *}$, Novita Sari ${ }^{1}$, Muhammad Rafiq ${ }^{1}$, Lilla Rahmawati ${ }^{2}$ \\ ${ }^{1}$ Program Studi Manajemen, Fakultas Ekonomi dan Bisnis, Institut Informatika dan Bisnis \\ Darmajaya \\ ${ }^{2}$ Program Studi Bisnis Digital, Fakultas Ekonomi dan Bisnis, Institut Informatika dan Bisnis \\ Darmajaya \\ *Correspondent Email: muhammadsaputra@darmajaya.ac.id
}

\author{
Article History:
}

Received: 23-12-2021; Received in Revised: 11-01-2022; Accepted: 28-01-2021

DOI: http://dx.doi.org/10.35914/tomaega.v5i1.977

\begin{abstract}
Abstrak
Pembatasan interaksi sosial berdampak pada pergerakan perekonomian salah satunya bidang Usaha Kecil Menengah (UKM) yang mengalami penurunan penjualan. Inovasi dan penggunaan teknologi merupakan hal yang menjadi sebuah keharusan bagi pelaku usaha untuk bertahan dimasa pandemi Covid 19. Berdasarkan hasil observasi yang dilakukan permasalahan penurunan penjualan dimasa pandemi Covid 19 juga terjadi pada Usaha Kecil Menengah (UKM) Bubuk Jahe di Desa Semuli Raya diantaranya kurangnya pemanfaatan teknologi sebagai alat untuk pengenalan dan pemasaran produk secara online. Oleh karena itu tim pengabdi berinisiatif untuk melakukan pelatihan berupa pelatihan inovasi produk serta strategi pemasaran pada UKM bubuk jahe di masa pandemi Covid 19 yang bertujuan untuk meningkatkan dan mengembangkan produk Bubuk Jahe, meningkatkan minat konsumen terhadap produk Bubuk Jahe dan memberikan pemahaman tentang pemanfaatan teknologi dalam bidang pemasaran produk secara online. Metode pelaksanaan kegiatan pengabdian masyarakat atau PKM ini dilaksanakan dengan metode persiapan, sosialisasi, pelaksanaan dan evaluasi. Berdasarkan hasil kegiatan pengabdian yang sudah dilaksanakan dicapailah hasil pelaku UKM bubuk jahe memiliki inovasi produk baru seperti bubuk temulawak, bubuk kunyit, bubuk kencur, dan rempah-rempah lainnya sesuai dengan yang di butuhkan oleh masyarakat, memiliki inovasi kemasan dan pemberian label untuk meningkatkan daya tarik dan membangun brand produk serta menerapkan pemasaran melalu media sosial.
\end{abstract}

Kata Kunci: Inovasi Produk, Strategi Pemasaran, UKM, Pelatihan

\begin{abstract}
This limitation of social interaction is the impact of economic movements, one of which is the Small and Medium Enterprises (SME) sector which experienced a decline in sales. Innovation and the use of technology are a must for business actors to survive during the Covid 19 pandemic. Based on observations made, the problem of declining sales during the Covid 19 pandemic also occurred in Ginger Powder Small and Medium Enterprises (UKM) in Semuli Raya Village including the lack of utilization technology as a tool for online product introduction and marketing. Therefore, the service team took the initiative to conduct training in the form of product innovation training and marketing strategies for ginger powder SMEs during the Covid 19 pandemic which aims to improve and develop
\end{abstract}


[ 143 ] Muhammad Saputra, dkk / To Maega: Jurnal Pengabdian Masyarakat, Vol.5; No.1; Februari 2022

Ginger Powder products, increase consumer interest in Ginger Powder products and provide an understanding of the use of technology in the field of Ginger Powder. online product marketing. The method of implementing community service activities or PKM is carried out by the methods of preparation, socialization, implementation and evaluation. Based on the results of the service activities that have been carried out, the results of ginger powder SMEs have achieved new product innovations such as ginger powder, turmeric powder, kencur powder, and other spices in accordance with what is needed by the community, have packaging and labeling innovations to increase attractiveness. and build product brands and implement marketing through social media.

Key Word: Product Innovation, Marketing Strategy, SME, Training

\section{Pendahuluan}

Saat ini Badan kesehatan Dunia (WHO) secara resmi menyatakan virus corona covid-19 telah menyebar beberapa negara dan menjadi status pandemi seperti di Indonesia. Perkembangan kasus Covid 19 masih menjadi fokus perhatian pemerintah Indonesia dengan mengeluarkan beberapa peraturan termasuk pembatasan aktivitas masyarakat dalam berinteraksi secara sosial (Muhlis et al, 2021). Hal ini dilakukan untuk memutus rantai penyebaran Covid 19 agar tidak semakin luas penyebarannya. Pembatasan interaksi sosial ini dampak pergerakan perekonomian salah satunya bidang Usaha Kecil Menengah (UKM) yang mengalami penurunan penjualan. Inovasi dan penggunaan teknologi merupakan hal yang menjadi sebuah keharusan bagi pelaku usaha untuk bertahan dimasa pandemi Covid 19 (Martina et al, 2021).

Berdasarkan hasil observasi yang dilakukan permasalahan penurunan penjualan dimasa pandemi Covid 19 juga terjadi pada Usaha Kecil Menengah (UKM) Bubuk Jahe di Desa Semuli Raya diantaranya (1) kurangnya pemanfaatan teknologi sebagai alat untuk pengenalan dan pemasaran produk secara online, sehingga diperlukan pelatihan dalam meningkatkan pengetahuan yang dapat mempengaruhi pendapatan bagi masyarakat (Ardiansyah \& Rudianto, 2018); (2) kurangnya inovasi terhadap produk, sehingga sangat penting untuk diketahui dalam meningkatkan daya tarik konsumen sehingga konsumen dapat merasakan varian lain selain dari Bubuk Jahe (Hamzah et al, 2019) ; (3) kurang pahamnya bagaimana cara memilih kemasan produk yang baik sehingga dapat menjaga kualitas produk (Didiharyono, 2016), serta (4) kurang pahamnya akan merek dan logo yang bisa meningkatkan daya tarik konsumen (Mubarat et al, 2021).

Kemajuan teknologi saat ini sedang berkembang dengan pesat mendorong pelaku Usaha Kecil Menengah (UKM) untuk menguasai bidang IT dalam proses bisnis yang dijalankan selain itu inovasi produk menjadi sebuah kepentingan dalam sebuah persaingan (Prasetyawat et al, 2021). Adanya sebuah inovasi produk mendorong pelaku Usaha Kecil Menengah (UKM) untuk terus bertahan ditengah perkembangan variasi produk yang masuk kedalam sebuah pasar (Pratika et al, 2021). Pengabdian Masyarakat merupakan suatu kegiatan yang bertujuan membantu masyarakat di suatu daerah dengan melakukan beberapa aktivitas serta 
mengimplementasikan ilmu di perguruan tinggi untuk penerapan secara nyata dalam kehidupan sehari-hari di masyarakat, secara luas (Solihin et al, 2021). Oleh karena, itu tim pengabdi berinisiatif untuk melakukan pelatihan berupa pelatihan inovasi produk serta strategi pemasaran pada UKM bubuk jahe di masa pandemi Covid 19 yang bertujuan untuk meningkatkan dan mengembangkan produk Bubuk Jahe,meningkatkan minat konsumen terhadap produk Bubuk Jahe dan memberikan pemahaman tentang pemanfaatan teknologi dalam bidang pemasaran produk secara online (Rivaldo et al, 2021).

\section{Metode}

Untuk dapat menyelenggarakan pelatihan yang baik, maka perlu dirancang program pelatihan tepat sasaran. Metode pelaksanaan kegiatan pengabdian masyarakat atau PKM ini dilaksanakan dengan metode persiapan, sosialisasi, pelaksanaan dan evaluasi. Berikut metode yang digunakan dalam pelatihan ini :

a. Persiapan

Pada tahapan persiapan yang dilakukan observasi pada UKM bubuk jahe Di

Desa Semuli Raya Kecamatan Abung Semuli Kabupaten Lampung Utara (Suwarsi et al, 2021)

b. Pemberian materi

Pada tahap ini pemberian materi diberikan kepada pelaku UKM bubuk jahe dan Perkumpulan petani jahe dengan jumlah peserta sebanyak 45 peserta. Pemberian materi yang dilakukan dengan pemberian mengenai inovasi produk dan digitalisasi UMKM (Wasan et al, 2021)

c. Pelatihan

Pelatihan ini dilakukan dengan praktek terkait dengan inovasi produk dan pemasaran dengan menggunakan internet (Wahyuningsih et al, 2021)

d. Evaluasi

Kegiatan Evaluasi kegiatan dilakukan untuk mengetahui feedback dari para pelaku UKM bubuk jahe dan perkumpulan petani jahe berupa tanggapan dan tindaklanjut yang akan dilakukan oleh para pelaku UMKM.

\section{Hasil dan Pembahasan}

\section{Inovasi Produk Baru Selain Bubuk Jahe}

Inovasi produk merupakan upaya pembuatan produk baru yang dilakukan untuk memperbaiki, meningkatkan, dan mengembangkan produk yang diproduksi selama ini. Inovasi suatu produk bisa terjadi dikarenakan ada beberapa hal di antaranya adalah adanya timbal balik (feedback) dari pelanggan, kombinasi hal yang sebelumnya sudah ada hingga penemuan sebuah produk baru. Tujuan melakukan suatu inovasi pada diri adalah untuk membuat manusia memiliki kualitas yang meningkat sehingga banyak sekali yang nantinya muncul kemampuan baru yang sebelumnya tidak di miliki. 
Begitu pula hal nya dengan inovasi produk terdapat tujuan tertentu yang ingin di capai ketika melakukan inovasi produk yaitu meningkatkan kualitas produk, memenuhi kebutuhan pelanggan,dan menciptakan pasar baru di tengah masyarakat. Manfaat dari inovasi produk adalah pelaku usaha yang membuat produk bisa terus berinovasi sehingga mampu mengalahkan pesaing-pesaingnya .Dari kegiatan ini lah pelaku usaha dapat mengembangkan produk bubuk jahe yang nantinya tidak hanya bubuk jahe saja yang di jual tapi berbagai produk seperti bubuk temulawak, bubuk kunyit, bubuk kencur, dan rempah-rempah lainnya sesuai dengan yang di butuhkan oleh masyarakat. Berikut hasil inovasi produk yang dilakukan dalam kegiatan pengabdian ini :

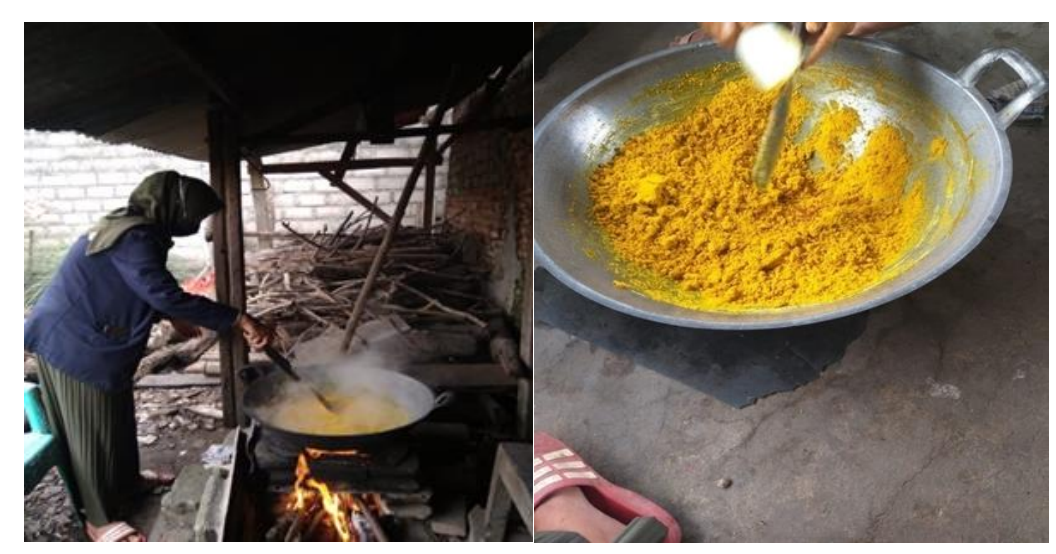

Gambar 1. Proses Inovasi Produk

\section{Inovasi Kemasan Pada Produk Bubuk Jahe dan Pemberian Label Guna Pengembangan Produk Usaha Mandiri Bubuk Jahe Ibu Sri}

Salah satu daya tarik dari suatu kemasan adalah di lihat dari segi cara pengemasan (Packing). Pengemasan merupakan suatu cara atau perlakuan pengamanan terhadap makanan atau bahan pangan, agar makanan atau bahan pangan baik yang belumdi olah maupun yang sudah di olah dapat sampai ke tangan konsumen dengan kualitas yang masih banyak dan pengemasan yang baik yang dapat melindungi kualitas produk. Kemasan juga bisa melakukan program pemasaran industri lewat kemasan identifikasi produk jadi lebih efisien. Label merupakan salah satu bagian dari produk berbentuk penjelasan baik foto ataupun perkata yang berperan bagaikan sumber data produk serta penjual. Label biasanya data berbentuk nama ataupun merk produk, bahan baku, bahan bonus komposisi, data gizi, bertepatan pada kadaluarsa isi produk serta penjelasan legalitisan. Fungsi label produk tersebut adalah label mempromosikan produk melalui aneka foto yang menarik.

Pada kegiatan ini Kemasannya nya di ganti dengan kemasan yang baru yaitu standingpouc, standingpouch sendiri memiliki keunggulan yaitu bahannya kemasannya yang tebal yang mampu menjaga kualitas produk agar tetap tahan lama dan kemasan ini juga sangat amatlah praktis untuk di bawa bepergian karena 
kemasan ini juga di lengkapi ziplock sehingga produk dapat saja di gunakan tanpa perlu takut bubuk tersebut tumpah. kemudian di berikan label pada produk untuk memperkenalkan produk bubuk jahe serta dengan di cantumkan varian yang di jual ,nama produk, media sosial yang bisa di hubungi hingga nomer telepon pelaku usaha. Berikut hasil inovasi pada kemasan produk yang dilakukan dalam pengabdian ini :

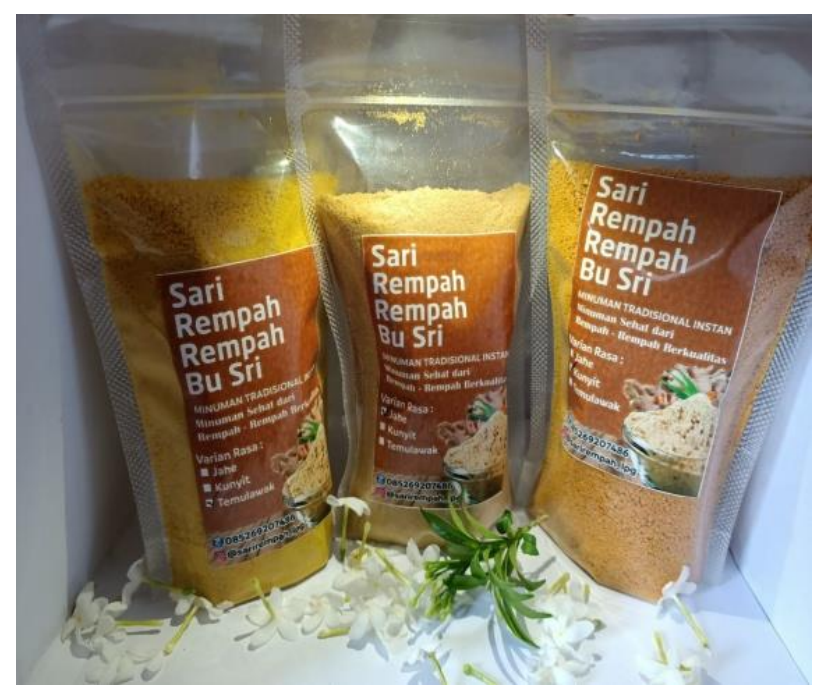

Gambar 2. Branding Produk

\section{Penerapan Pemasaran Dengan Menggunakan Media Sosial}

Pemasaran media sosial saat ini merupakan bagian integral dari kehidupan bisnis banyak pengecer online dan perusahaan, bahkan dalam beberapa kasus sebagai strategi pemangku kepentingan dalam lingkup rencana bisnis. Terutama di sektor barang konsumsi, hampir setiap perusahaan memiliki setidaknya satu profil sosial. Manfaatnya sendiri dari pemasaran dengan menggunakan media sosial adalah membangun dan menarik minat masyarakat, mudah berinterkasi dengan konsumen apalagi di masa pandemi ini yang semua aktivitasnya di batasi, serta dapat meningkatkan penjualan. Media sosial sendiri di anggap menjadi media yang sangat efektif untuk meningkatkan penjualan serta pendapatan.

Kegiatan ini bertujuan untuk memperkenalkan produk dan menarik minat konsumen untuk membeli. Pada kegiatan ini di lakukan pembuatan media sosial instagram yang nanti pelaku UKM bubuk jahe dapat menggunakan media sosial tersebut sebagai sarana penjualan produk hasil olahan serta pengenalan kepada kelompok petani jahe sebagai sarana penjualan online. Berikut hasil media sosial yang dilakukan dalam pengabdian ini. 
[ 147 ] Muhammad Saputra, dkk / To Maega: Jurnal Pengabdian Masyarakat, Vol.5; No.1; Februari 2022

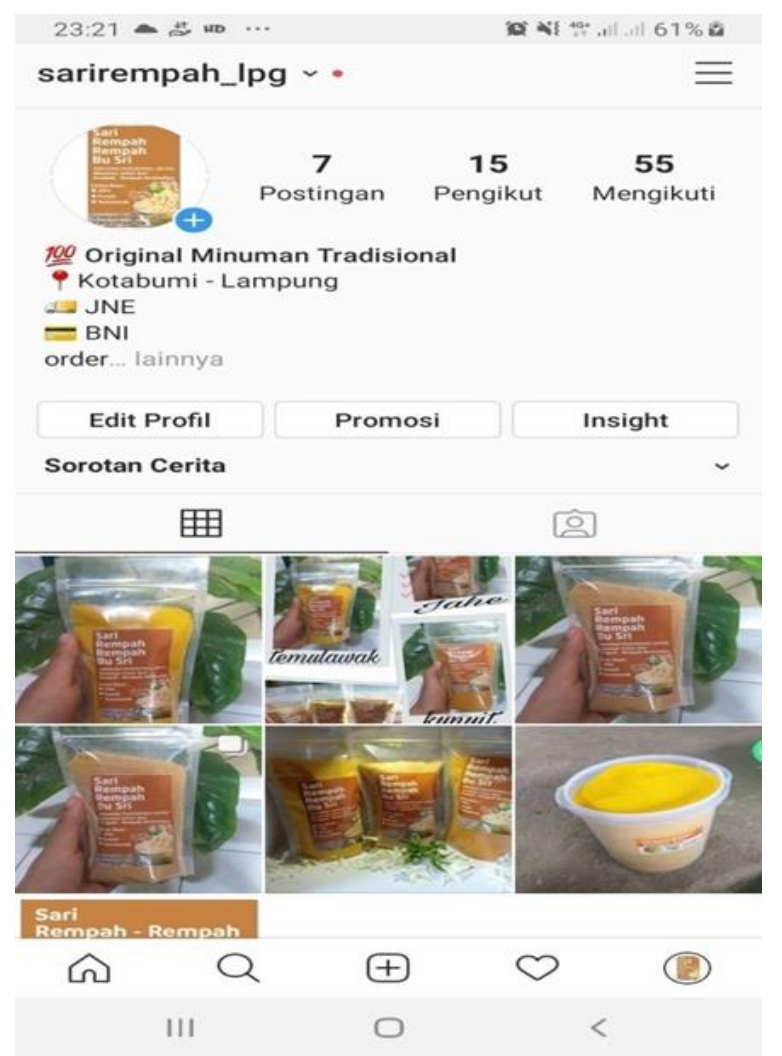

Gambar 3. Media Sosial Instragram UKM Bubuk Jahe

Dampak dari kegiatan yang sudah terprogram dan di laksanakan pada tanggal yang sudah di tentukan adalah berdampak sangat baik bagi masyarakat, khususnya pelaku UKM Bubuk Jahe dan Kelompok Petani Jahe dimana kurang paham pentingnya pengemasan yang baik dan menarik saat ini sudah dapat di terapkan dalam kehidupan sehari-hari seperti mengganti kemasan dengan yang lebih menarik dan pemberian label untuk memperkenalkan produk ke masyarakat luas. Dalam kegiatan tersebut pula tim pengabdian melakukan inovasi produk tidak hanya memproduksi bubuk jahe saja tetapi terdapat varian lain yang di tambahkan yaitu bubuk kunyit dan bubuk temulawak yang khasiatnya juga sama sama bagus untuk di konsumsi dan baik untuk kesehatan tentunya praktis dalam penyajiannya. Selain itu juga kegiatan ini juga pelaku UKM bubuk jahe dan kelompok petani diberikan pengetahuan mengenai pemasaran digital menggunakan media sosial instagram yang dapat memperluas jaringan pemasaran.

\section{Kesimpulan}

Berdasarkan dari beberapa kegiatan pengabdian yang sudah di laksanakan dapat disimpulkan sebagai berikut:

1. Meningkatkan produk dan mengembangkan inovasi produk selain bubuk jahe dengan cara membuat produk bubuk temulawak 
[ 148 ] Muhammad Saputra, dkk / To Maega: Jurnal Pengabdian Masyarakat, Vol.5; No.1; Februari 2022

2. Meningkatkan minat beli konsumen terhadap produk dengan menggunakan kemasan terbaru dan label produk

3. Memberikan edukasi atau pemahaman kepada pelaku UKM dan kelompok petani jahe terkait pemanfaatan teknologi untuk pemasarannya dengan cara membuat akun media sosial instagram agar mempermudah mereka mengenalkan produk dan menarik konsumen sehingga memajukan usaha mereka.

\section{Ucapan Terima Kasih}

Terima kasih kepada Menteri Riset dan Teknologi, Republik Indonesia yang menyediakan dana untuk penelitian hingga selesai. Juga sangat berterima kasih kepada pusat penelitian, Darmajaya Informatics and Business Institute yang telah mendukung penyelesaian penelitian ini. Akhirnya, terima kasih banyak kepada semua orang yang tidak bisa semua disebutkan dalam ruang ini dalam membantu kami menyediakan segalanya untuk menyelesaikan pekerjaan ini.

\section{Daftar Pustaka}

Ardiansyah, M. A., \& Rudianto, R. (2018). Pengembangan Dan Penerapan Teknologi Tepat Guna Pada Industri Rumahan Pembuat Produk Lokal Berbahan Dasar Sagu Di Kota Palopo. To Maega: Jurnal Pengabdian Masyarakat, 1(1), 29-34.

Didiharyono, D. (2016). Penerapan Metode Statistical Processing Control Untuk Menganalisis Pengendalian Kualitas Produk pada PT. Asera Tirta Posidonia. Jurnal Equilibrium 2 (4), 325-332

Hamzah, H., Idhan, A., \& Syamsia, S. (2019). Diseminasi Teknologi Pengelolaan Limbah Pertanian Menjadi Produk Bernilai Ekonomi Tinggi Dalam Upaya Mendukung Kesejahteraan Petani. Jurnal Dedikasi Masyarakat, 2(2), 83-91. Martina, N., Hasan, M. F. R., \& Wulandari, L. S. (2021). Upaya Peningkatan Nilai Ekonomis Produk Umkm Melalui Sosialisasi Diversifikasi Produk. Jmm (Jurnal Masyarakat Mandiri), 5(5), 2273-2282.

Mubarat, H., Iswandi, H., \& Ilhaq, M. (2021). Pelatihan Inovasi Dan Pengembangan Produk Patera Eco Print Palembang. Selaparang Jurnal Pengabdian Masyarakat Berkemajuan, 4(2), 329-333.

Mukhlis, M., Kasmawati, K., \& Raznilawati, Z. (2021). Bentuk Kepedulian Antar Sesama Lewat Berkah Ramadhan di Tengah Wabah Covid-19. To Maega: Jurnal Pengabdian Masyarakat, 4(1), 55-62.

Prasetyawati, Y. R., Setyaningtyas, E., Ayu, J. P., Sartika, K. D., \& Adithia, S. (2021). Pelatihan Culinary Entrepreneur Dalam Mengembangkan Kinerja Umkm Di Masa Pandemi. Journal Of Servite, 3(1), 31-43.

Pratika, Y., \& Praharjo, A. (2021). Pendampingan Inovasi Produk Olahan Telur Asin Di Desa Pendem Kecamatan Junrejo Kota Batu. Budimas: Jurnal Pengabdian Masyarakat, 3(1). 
[ 149 ] Muhammad Saputra, dkk / To Maega: Jurnal Pengabdian Masyarakat, Vol.5; No.1; Februari 2022

Rivaldo, Y., Yusman, E., \& Sidik, M. (2021). Pelatihan Strategi Daya Saing Usaha Dalam Perspektif Ekonomi, Pendidikan Dan Psikologi Kepada Mahasiswi Institut Agama Islam Abdullah Said Batam. Jurnal Al Tamaddun Batam, 1(1), 13-16.

Solihin, D., Ahyani, A., Karolina, K., Pricilla, L., \& Octaviani, I. S. (2021). Pelatihan Pemasaran Online Berbasis Digital Untuk Meningkatkan Penjualan Bisnis Online Pada Umkm Di Desa Cicalengka Kecamatan Pagedangan Kabupaten Tangerang. Dedikasi Pkm, 2(3), 307-311.

Suwarsi, A. A., Satyarini, J. N. E., Hayati, S. R., Sharfina, A. G., \& Anggraeni, A. (2021). Inovasi Produk Pengrajin Gerabah Di Dusun Jetis, Panjangrejo, Pundong Bantul Yogyakarta. Pengabdianmu: Jurnal Ilmiah Pengabdian Kepada Masyarakat, 6(2), 197-205.

Wahyuningsih, R., Anggraini, P. N., Vebyanti, S. E., \& Susanti, A. (2021). Pelatihan Pembuatan Bucket Bunga Dan Snack Untuk Meningkatkan Kreativitas Peserta Didik Di Jombang Jawa Timur. Indonesian Journal Of Community Service, 1(3), 523-531.

Wasan, G. H., \& Sariningsih, A. (2021). Pelatihan Pemasaran Produk Usaha Mikro Kecil Dan Menengah (Umkm) Berbasis Digital Di Kecamatan Citeureup. Jurnal Pengabdian Masyarakat Madani (Jpmm), 1(1), 31-36. 